\title{
Preparing for talent: Towards transformed indigenous African language disciplines at South African universities
}

\author{
Paul H. Nkuna \\ Department of African Languages, University of South Africa \\ P.O. Box 392, UNISA 0003, Pretoria, South Africa \\ nkunaph@unisa.ac.za
}

\begin{abstract}
This study investigated the challenges facing higher education institutions in South Africa in retaining and recruiting talent, especially in the discipline of indigenous African languages. A survey was conducted among a number of academics of nine universities in South Africa. Of the potential respondents of 50,34 or $68 \%$ returned the questionnaires. The study first investigated the post-levels of respondents before measuring their age and the length of service. The effects of the generation gap as revealed by the responses, formed the independent variable. A clear indication of the generation gap could be observed with regard to two specific factors: post-levels and length of service. The post-levels of the total number of respondents support the claim that universities neglect young talent. The generation gap shows that African language departments are steered by aging staff members. The long service periods of current staff members indicate that human resource managers at universities have put a stop to staffing their African language departments. Some strategies could be adopted by higher education institutions in addressing the shortage of talent in indigenous African language disciplines.
\end{abstract}

\section{Introduction}

Attempts to describe the haunting question of the value and role of the future academic of indigenous African languages is a deepening mystery and an elusive task. So, how can one describe the academics of tomorrow in indigenous African language disciplines? Do these language disciplines operating in South African universities hold the seeds of change now manifest in the trends impacting on academics at the dawn of transformation? South African human resource professionals in general, and those working at universities in particular, should be prepared to identify some of the critical realities facing academics today and in the future. The best South African universities' human resource professionals should remember the increasing challenges faced by universities today in addressing the racial and gender inequalities which exist at present in the system, and which have given rise to inefficiencies. Inequalities in the country's higher education system are significant forces at all levels, and they can be grouped into six categories: access, outputs and throughputs, staff, research and research output, governance, and funding (Ministry of Education, 1996). This means that an article on this topic, even in the discipline of African languages in higher education, must necessarily be selective in its focus.

Solving problems generated by inequalities will increase the challenges inherent in the South African universities' human resource function. This article describes the impact of talent on the academic staff members of indigenous African language disciplines operating at these universities. Firstly, an overview of the theoretical framework for identifying talent in general and the challenges facing South African universities' human resource professionals in transforming the indigenous African language disciplines in particular, is presented. Secondly, the research methodology to be used for establishing the present circumstances of academic staff in the field is outlined. The third concern of this research is to present the results of the survey questionnaire sent to 50 respondents of academic staff members at nine universities of South Africa. Fourthly, these results are discussed and recommendations are suggested to help human resource professionals in general, and human resource professionals at South African universities in particular, to focus on the challenges involved in the efficient and effective management of the transformation in the African language disciplines as well as in recruitment, staff development and deployment. 


\section{Theoretical framework and challenges}

Universities have opportunity to employ many people who are talented and who deeply want to achieve happiness and success. In the context of this article, the focus is on recruiting talented young people in departments of African languages as well as growing talent from within these departments. African language departments, however, appear to be battling to attract and train young people to become African language academics, and this is hampering the contribution by the universities towards the country's agenda of promoting and developing the African languages. In addition, it would also have the effect of weakening African language departments at universities - and eventually start weakening the production of African language-literature and performing arts. As the South African Constitution of 1996 (Act 108 of 1996) recognizes nine of the indigenous languages as official, universities will return to the challenge of winning over highly capable indigenous language professionals to effect the development and promotion of those nine indigenous languages to their official use and status. Only then will the South African universities realize that the rules of engagement have changed - that the landscape of indigenous languages talent management has been transformed. This has a direct impact on how African language departments should retain talent from the Baby Boomers (people who were born between 1945 and 1964) to Generation X (people who were born between 1965 and 1978); and recruit talent from Generation Y (people who were born between 1979 and 1994). By employing people from the Y generation, indigenous language departments could improve the official use and status of indigenous languages in the country.

Thompson, Marshall and Waite (2003:847) say talent refers to 'a special aptitude or ability, a high mental ability, a person or persons of talent'. Wooldridge (2006:4), however, argues that Thompson and his co-authors tried to avoid defining talent either too broadly or too narrowly by 'simply taking it to mean brainpower - the ability to solve complex problems or invent new solutions', while Moon (2003:11) maintains that talent is a 'developed expertise in a specific domain'.

As far as a university is concerned, 'an employee is first and foremost expected to fulfil a function, with a number of tasks for which a number of skills are required. Some of these tasks are technical and some are related to the employee's relationships with co-workers and outside agencies' (Joerres \& Turcq, 2006:1). In the case of teaching and research employees, these tasks involve delivering three main services - teaching, research, and community service. Higher education institutions must employ people with brainpower who are competent and committed to delivering services. Thus, African language departments require talented academics who are competent and committed to teach and research within the indigenous African language disciplines, and who are also prepared to deliver African language and literature services to the society. 'Both Boomers and Gen[eration] Ys want to contribute to society' (Hewlett, Sherbin \& Sumberg, 2009:72). It is believed that they show the way to tomorrow's best practice. Therefore, African language departments' demands have significant practical implications for how employers in South African higher education institutions should design working environments to attract and keep talent. Thus, these higher education institutions face the massive challenges that emanate from a dramatically changed environment. The challenges include:

(1) The March 2001 release of a National Plan for Higher Education that incorporates 11 key proposals. Two of these key proposals are (a) that there will be a shift in the balance of enrolment over the next 5 to 10 years between the humanities, business and commerce, and science, engineering and technology from the current ratio of 49:26:25 to 40:30:30 respectively, and (b) institutions will develop employment-equity plans with clear targets for rectifying race and gender inequalities.

(2) The former Minister of Education Kader Asmal's 2002 announcement of guidelines for the merger process, which would see South Africa's 36 higher education institutions, formerly arranged according to the recommendations of the 1974 van Wyk De Vries commission and the 1985 Goode committee under eight different education departments to slim them down to 22 higher education institutions operating under a single department. Several of these institutions were to be 'comprehensive' - the Nelson Mandela Metropolitan University, the University of Johannesburg, the University of South Africa, the University of Venda and the University of Zululand. 
(3) The threefold role of the new single higher education system that incorporates human resource development, higher-level skills training, and production, and the acquisition and application of new knowledge (Burger, Cronjé \& Tibane, 2003).

Every turnaround has its sceptics. Five years down the line it is still difficult for the higher education institutions to execute the two key proposals mentioned above [see (a) and (b) in (1)], to determine how the two curricula (university and technikon) work together, and how to execute the present threefold role of higher education. Most of the difficulties have arisen from the fact that for many years, apartheid was used to channel students to enrol for Arts and Human Science programmes, and African language disciplines enjoyed a high number of student enrolments, leading to the appointment of many academics to teach in these disciplines. In 1997, the Department of African Languages at the University of South Africa (UNISA), for example, had in its employ 90 staff members. In the intervening years, staff numbers declined steadily, and by 2005, there were only 72 staff members (a drop of $20 \%$ in eight years). Since then, the number of staff members has dropped very fast, but not because of natural factors such as retirement, but rather as a result of imposed human capacity curtailment. Today, the department has 26 staff members (a drop of $63.9 \%$ in five years).

There are many factors that may be contributing to the low percentage of academics in indigenous African languages. For instance, 'the unemployment rate and the incidence of unemployment differ for graduates and are influenced by factors such as study field ... humanities and arts has the highest proportion (53.3\%) of those unemployed' (Moleke, 2006:15). This is followed by education, with 17.9\% of those unemployed. Indigenous African language programmes form part of the humanities and the arts; they were designed and developed as subjects in the field of humanities and arts, to be on the list of courses for teaching degrees with humanities and arts subjects. They were not primarily developed for other fields of study such as the natural sciences, engineering, agriculture, medical sciences, law and economic and management sciences. 'New graduates were "handicapped" by higher institutions that placed too little emphasis on practical learning and application' (Ntuli, 2007:1).

In short, employment in indigenous African language disciplines is declining. The new higher institutions fail to integrate science with practical learning and practice. They focus on maintaining their status in science and neglect practical learning and application. Similarly, the indigenous African language disciplines in these institutions are becoming what Codrington (2007:33) referred to as 'prisoners of their past - not feeling any need to push boundaries, innovate, prepare for the unexpected, stretch themselves or make necessary changes to sustainable success'. Their curricula do not cater for Generation Y, and they also 'face intense criticism for failing to lead graduates to good corporate jobs' (Nkuna, 2006:30).

All these difficulties seem to be the result of a gap between what the indigenous African language disciplines are expected to achieve in fields other than the humanities and the arts, and the ability of the academic staff to achieve those requirements. To bridge this gap, talent development and recruitment should be high on the agenda. In the past, academic staff members were not integrating science, practical learning and application.

\section{Research methodology}

In 2008 , the author conducted a survey using a questionnaire sent via the post to a sample of 50 respondents drawn from a population of academic staff members at nine universities - Tshwane University of Technology, University of Cape Town, University of the Free State, University of Kwazulu-Natal, University of Limpopo, University of South Africa, University of Pretoria, University of Zululand, and the Venda University of Technology. The academic staff members were sub-divided into distinct groups of full professors, associate professors, senior lecturers, lecturers and junior lecturers. The following three questions were asked to the respondents: 
1. What is your post-level in the department?

(Please, cross (X) the box for the appropriate answer).

Full Professor

Associate Professor

Senior Lecturer

Lecturer

Junior Lecturer

Other. (Please, specify)

2. How old are you?

(Please, cross $(\mathrm{X})$ the box that represents the appropriate answer).

Less than 30 years

Between 30 and 40 years

Between 40 and 50 years

Between 50 and 60 years

$60+$

3. For how long have you served your department?

(Please, cross (X) the box that represents the appropriate answer).

Less than 3 years

$3-5$ years

5-10 years

10-15 years

15-20 years

$21+$

Microsoft Excel was utilized to analyse the responses.

\section{Statistical research results}

Following the investigation and the analysis of the questionnaire responses, the following results were obtained. Three important aspects were reflected: 


\section{Number of respondents}

Only 34 respondents or $68 \%$ of the sample returned the questionnaires (See Figure 1 below):

Figure 1: Respondents

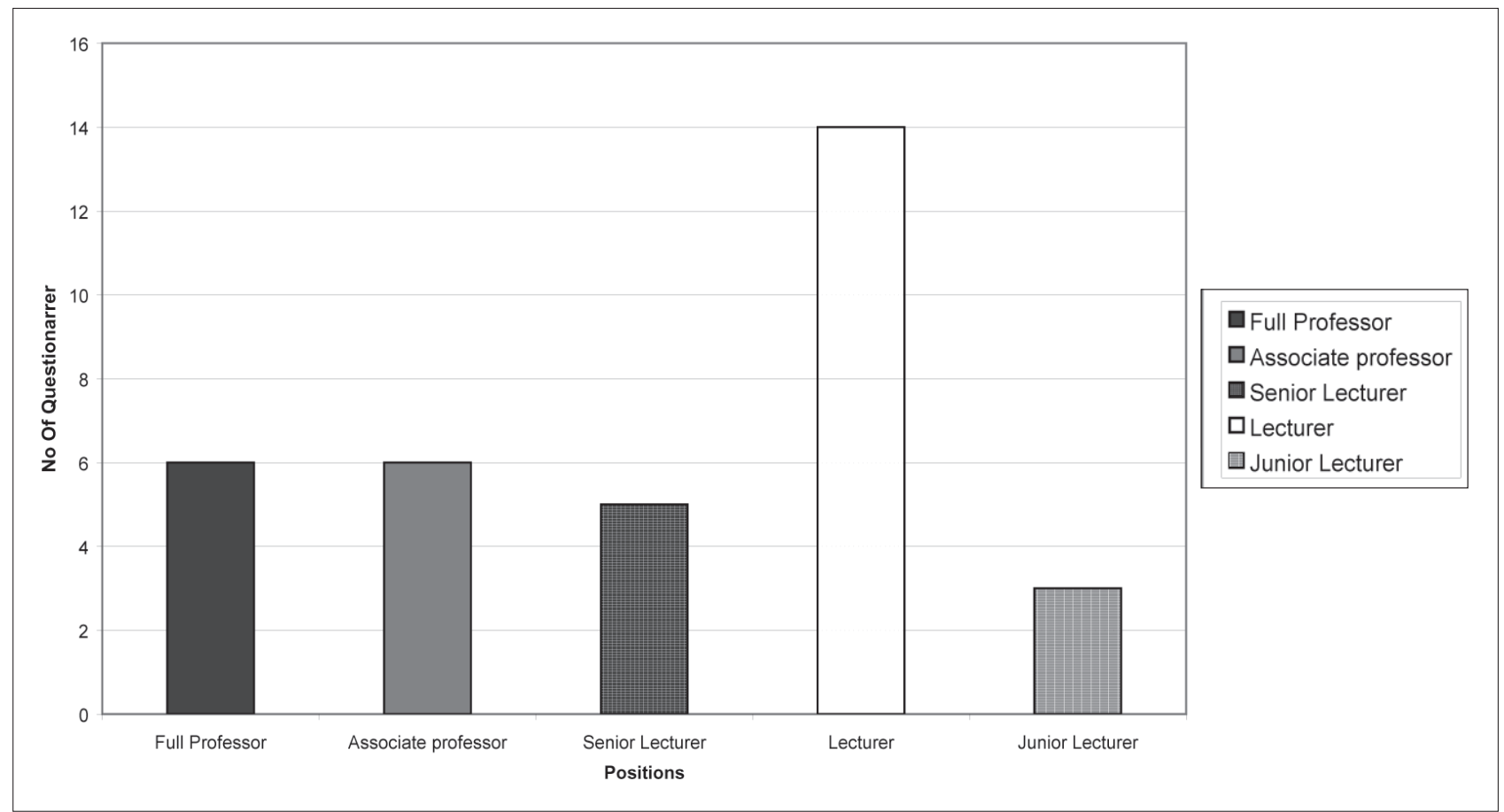

From the graph, one can observe four features in the responses supporting the claim that universities neglect young talent. These features are:

- the majority of respondents occupy the rank of lecturer - representing $41.2 \%$ (14) of the total number of respondents.

- the second largest group is made up of full and associate professors - combined to represent $35.3 \%$ (12) of the total number of respondents.

- the third largest group is made up of senior lecturers $-14.7 \%$ (5) of the total number of respondents.

- the smallest group consists of junior lecturers - only $8.8 \%$ (3) of the total number of respondents. 


\section{The greying workforce}

Figure 2 below indicates the respondents' ages. The graph reveals that academic staff members in African language departments or centres are ageing.

\section{Figure 2: Respondent age}

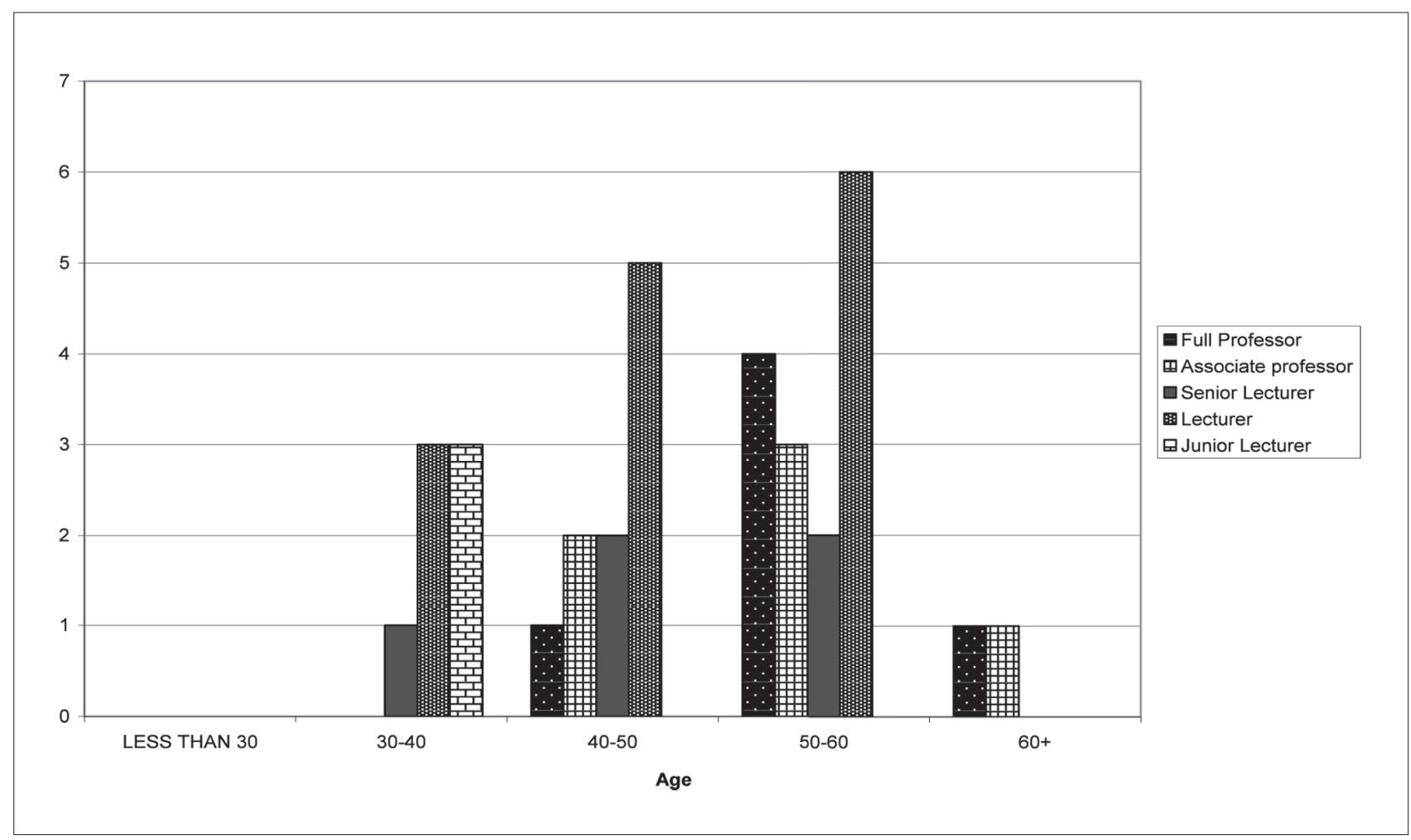

From the graph, three features, which confirm the presupposition that African language departments or centres are steered by greying academic staff members, become clear. These three features are:

- The majority of respondents are between 50 and 60 years old - representing $15(44.1 \%)$ of all the respondents. Many in this age group occupy the position of lecturer - six (17.6\%) of the respondents. Only four $(11.8 \%)$ of the respondents aged between 50 and 60 are full professors. Three $(8.8 \%)$ are associate professors and two $(5.9 \%)$ are senior lecturers. No junior lecturer in this age group responded.

- The next largest group of respondents is aged between 40 and 50 - representing $29.4 \%$ (10) of the total number of respondents. Many in this age group also occupy the rank of lecturer - five $(14.7 \%)$ of all respondents. Only four (11.8\%) in this age group are associate professors or senior lecturers, and only one $(2.9 \%)$ of the respondents in this age group is a full professor. No junior lecturer in this age group responded.

- The lowest age group is between 30 and 40 years old - seven (20.6\%) of the respondents. Many respondents in this group are lecturers and junior lecturers. There are three lecturers $(8.8 \%)$ of the total respondents and three junior lecturers $(8.8 \%)$ of the total respondents as well. There is only one senior lecturer $(3.0 \%)$ of the total respondents. There are neither associate-professors nor full-professors who responded in this age group. 


\section{Respondents' employment period}

None of the respondents had been appointed in the past five years (see Figure 3 below).

Figure 3: Service period

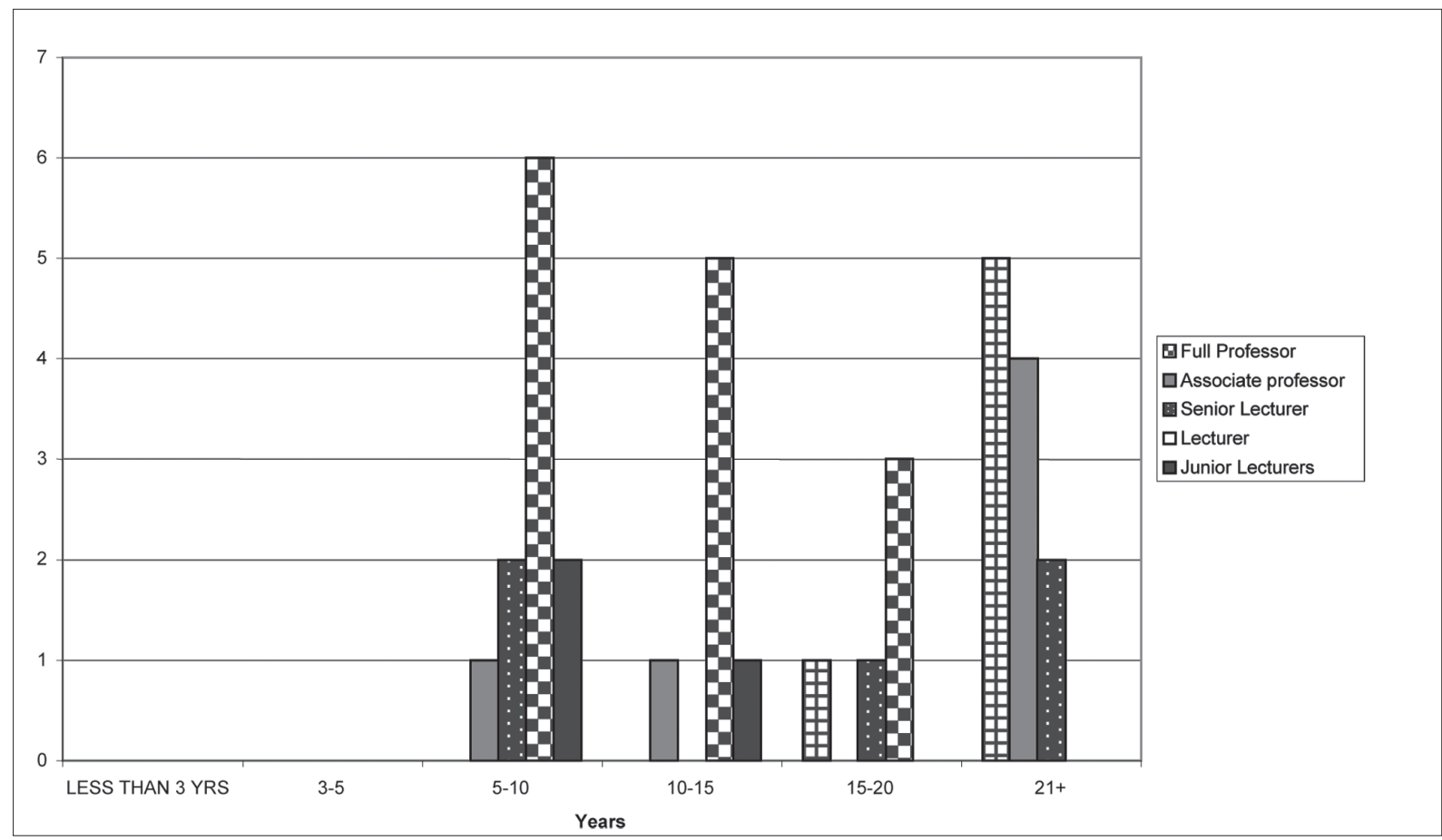

It is clear from the graph that human resource managers at universities have put a stop to staffing their African language departments or centres:

- The majority of the respondents fall into two groups: they have served their departments for between 5 and 10 years or for over 21 years, respectively. Each group represents 32.4\% (11) of the total number of respondents. Many respondents in the 5 to 10 years' service group are lecturers - six (17.6\%) of all respondents. There are four $(5.9 \%)$ senior lecturers and two $(5.9 \%)$ junior lecturers in this group. Only one $(2.9 \%)$ of the respondents in this group is an associate professor. Meanwhile, many respondents in the group with more than 21 years' service are full professors - five (14.7\%) of all respondents. There are four (11.8\%) respondents who are in the position of associate professorship, and two (5.9\%) are senior lecturers.

- The second highest number of respondents following the two groups above has served their departments or centres between 10 and 15 years - seven (20.6\%) of the respondents. Many respondents in this group are lecturers - five (14.7\%) in total. Junior lecturer and associated professor make up the remaining two positions (5.9\%).

- The group with the lowest number of respondents had worked between 15 and 20 years - five (14.7\%) of the total number of respondents. Three of these are lecturers $-8.8 \%$. Full professorship and senior lectureship make up the remaining two positions $(5.9 \%)$.

The nature of leadership in South African higher education institutions influences the present situation. The type of leaders still running South African universities believe that cost cutting is a major consideration, but they fail to capitalize on talent drivers that could overcome the inability to innovate. 'Innovation is the fuel of growth' (Hamel \& Getz, 2004:76). 


\section{Discussion and recommendations}

The statistical results of this study provide a clear picture of possible reasons for the failure of indigenous language disciplines at higher education institutions in South Africa. More specifically, it is important to note that higher education institutions may have neglected the talent in these disciplines. The following points support this contention:

- the majority of the respondents are concentrated at the level of lectureship. This could be a major factor in the slow pace of staff transformation in African language departments at universities. It could be the result of few or no promotions occurring from lectureship rank to senior ranks, such as senior lectureship, associate professorships and full professorships;

- the respondents are populated by Baby Boomers (people above 43 years of age in 2008), followed by members of Generation X (people above 30 years of age in 2008). There are no members of Generation Y (people below 30 years of age in 2008). This could be the result of only a few or no applicants being given opportunities or being prepared to take the place on the present academic staff;

- none of the 34 respondents took their positions within the past five years (between 2003 and 2008) - all had served their departments for more than five years. The majority indicate that they have worked more than 21 years in their departments. This could be the result of few or no applicants being given opportunities or being groomed to take the place of present incumbents.

The gap between talent and the changed environment in South African higher education is obvious and widespread. This talent gap leaves the indigenous African language disciplines engaged in what Harvard scholars refer to as 'experiencing a steady attrition in talent or retaining people with outdated skills' (Cohn, Khurana \& Reeves, 2005:64). However, 'operations are linked with strategic goals and human capacities' (Bossidy, Charan \& Burck, 2002:23). Similarly, operations of the indigenous African language disciplines are linked to the higher education institutions' strategic goals. Failing to capitalize on talent, indigenous African language disciplines could be overcome by an inability to innovate. When these disciplines run out of talent, they run out of growth, since real growth depends on innovation. If South African higher education institutions neglect talent, automatically they neglect innovation, growth and culture change. This is seen from the absence of Generation $\mathrm{Y}$ in the employ of departments of African languages.

What should higher education institutions in South Africa be doing to redress this problem? It is recommended that these institutions implement talent recruitment and retention strategies that attempt to address the talent gap that prevails at these institutions, especially within the indigenous African language disciplines. This talent gap in indigenous African languages could be addressed in the following six ways:

\section{Establishing a new kind of organization}

Central to current thinking on how the organization of indigenous African language disciplines should be transformed is the idea that this will depend on knowledge workers or professionals. These knowledge workers represent a large percentage of the workforce at any university. Universities should encourage every academic to consider him or herself a knowledge worker, and to think creatively about improving his or her particular corner of the organization for the sake of the higher institution. Higher institutions should concentrate on designing the processes that academic staff members carry out, rather than paying lip service to measuring their performance. The main tasks of higher education managers should be to judge the most important trade-offs for their particular teaching and research activities and then decide who is best placed to make decisions on these trade-offs, and finally, to delegate responsibility accordingly. 


\section{Capitalizing on talent}

This should involve focusing on egalitarianism; in this case, egalitarianism 'relates to the selection and development of talent' (Gratton, 2002:81), which 'comes from employees who are energized, have hopes and dreams, are prepared to be flexible and adaptable, and are creative and risk takers' (ibid., 2002:82). This requires that higher education institutions become highly efficient in attracting, motivating, and training young talent in the indigenous African languages. Managers should attract, motivate, and retain competent and committed people. Committed people are those who have skills for both today and tomorrow's discipline requirements, and they should deploy those skills regularly and predictably. Competence comes as leaders acquire new talent, develop existing talent, remove poor performers, and keep the best talent (Ulrich \& Smallwood, 2004). Higher education institution managers can earn commitment from employees by ensuring that the ones who contribute more receive more of what matters to them.

\section{Talent review}

'The talent review is the main social operating mechanism of the people process' (Bossidy et al., 2002:157). The circumstances of academic staff shown in the graphs above, indicate a deficiency in the talent review within South African higher education institutions. This is supported by the fact that the majority of the respondents is concentrated at lectureship level and has spent many years in the same position. This requires that the higher education institutions in general, and the faculties or colleges under which the indigenous African language disciplines operate, in particular, take a proactive stance on evaluating the academics in current positions and those who are available to succeed them. They should identify people who could move in and those who should be promoted in the next year because of their potential. In the talent review process, higher education institutions and faculties or colleges should also review people who are not performing, and debate alternatives. Such alternatives could include mentoring or coaching to help such people to adapt to the changed environment. Higher education institutions and faculties or colleges should have back-up candidates to replace people who might leave or be removed. In the talent review, higher education institutions and faculties or colleges should also address the indigenous African language discipline design, general talent development, and the skills gap that the discipline needs to bridge in order to execute the institution strategy.

\section{Paying close attention to the age of academic staff members}

Higher education institutions should take a proactive stance in preparing for the recruitment and retention shift in the age of academic staff members. "The "aging workforce" from a legal perspective begins with protections from age 40' (Beatty \& Burroughs, 1999:62). The statistics in this study reveal that, at the moment, the respondents belong to this age group or are older. The following questions arise: Are South African universities waiting for this group to retire so that the indigenous African language disciplines totally disappear, or are they waiting for this group to retire so that they can hire new academic staff members for the indigenous African language disciplines? Do they want to retain older academic staff members in these disciplines after their retirement? Do they want to change the compulsory retirement age of 65 years and allow older staff to remain longer in the workforce? In preparing to answer these questions, one should consider that 'people who look old are often the victims of stereotyping and discrimination based on age, even when they are physically fit and functionally independent' (Moody, 1998:8). Along this line, Beatty and Burroughs (1999:599) maintain that 'as workers age they tend to receive less training for maintaining, upgrading, or developing skills than younger workers. Management is less likely to authorize participation in training opportunities for the more mature members of the workforce'. Therefore, issues such as health and well-being, work, retirement, education, and lifespan development are the cause of the problems of ageism (Weaver, 1999). Thus, 'with the rapid development of new knowledge and technology, older workers are as likely as any to require frequent up-skilling, even at the end stage of their careers. Yet, research on training for older workers has suggested that negative perceptions of their competence may be due, not to age, but to insufficient training and poor learning-programme design' (Koopman-Boyden \& Macdonald, 2003:35). 
'In terms of training preferences, younger workers in their 40s have a primary interest in training for job mobility rather than on upgrading their job skills. Workers 50 years of age and older place priority on upgrading their current skills and less emphasis on job mobility' (Beatty \& Burroughs, 1999:600). However, 'the very nature of academic work may allow older academics to continue to undertake a special project or work on the consultancy basis, to mentor younger staff, or to teach a small post-graduate class while also moving into retirement' (Koopman-Boyden \& Macdonald, 2003:35). With these views of Koopman-Boyden and Macdonald, Moody, Beatty and Burroughs, and Weaver in mind, South African higher education managers should pay closer attention to the age of academic staff members. They should not wait for all academic staff members in the indigenous African language disciplines to retire, and then start planning. The change in the higher education environment requires a balance between the old and the young. A career development strategy, focused on individual and organizational needs, may promote specialization in a particular area of teaching or research and offer opportunities for creativity and skills development.

\section{Quality assurance}

'The search for consensual, effective and meaningful agreements over the purposes, means and outcomes of quality assurance continues to tax the inventiveness of academics, administrators and other stakeholders in many institutions of higher education, educational systems and quality assurance agencies' (Gordon, 2002:97). 'In South Africa, the National Plan for Higher Education paved the way for major restructuring and transformation. In addition to employment equity and a new funding formula, quality assurance has been identified as a steering element in the transformation process' (Wilkinson, 2003:161). 'Astin advocates a talent development conception of excellent staff, not because of their reputations or resource base, but because they can develop the talents of their institutional members' (Tam, 2002:214). Therefore, people are one of the key criteria for an institutional quality management plan (Liston, 1999). For a change in indigenous African language disciplines to be effected, it will have to be implemented by people. 'If people do not "own" the change then attitudes towards the system will be negative and untruthful, meaning that optimum results of the system's change cannot be achieved' (Spencer-Matthews, 2001:57). Wilkinson (2003) outlines two key factors in relation to people among the 11 key lessons learnt about quality assurance at the University of the Free State. These two key factors are:

- providing academic staff members with guidance at a very high level and empowering them to take ownership of the quality assurance process at faculty/departmental level;

- addressing the staff members' problems honestly with regards to the execution of the self-evaluation process and providing as much support as possible.

These two lessons learned by the University of the Free State, are crucial for the fostering of talent in the indigenous African language disciplines operating in the country's universities, if these disciplines are to succeed in the changed environment.

\section{Porter's (1990) three generic strategies}

Porter's three generic strategies are cost leadership, focus, and differentiation. A cost leadership strategy is good for South African higher education institutions in general and their indigenous African language disciplines in particular, because in this country both are developed as service providers. Focus would also benefit South African higher education institutions in general and their indigenous African language disciplines in particular if the institutions or departments concentrated on either one segment (the student) or narrower segments (teaching, research and community development), and thus build up a specific knowledge for student development teaching, research and community development. Lastly, differentiation can be achieved if the benefit of service and Programme Qualification Mix (PQM), which is relevant, corresponds to the national interests and is responsive to systematic, incremental innovations, continuing to add student and stakeholder value. 


\section{Conclusion}

Talent recruitment and retention is critical for the indigenous African language disciplines at South African universities if they are to provide essential knowledge and skills for transformation. The circumstances of academic staff members in these departments, as revealed in the statistical results above, warn of the demise of these disciplines. It indicates that the country's university managers are neglecting the hiring of young academic staff members (Generation Y). In this context, indigenous African language disciplines remain the fields of survival. Surely, the point of being a university discipline is to do something remarkable, not merely to survive. University African language studies should be a discipline of success, and the basis of success is talent.

This article has sounded a note of caution. It outlined the need for universities to consider new young talent (Generation Y) as a force for change, while retaining older staff members (Baby Boomers and Generation X). University managers who ignore talent recruitment and retention automatically neglect innovation, growth and cultural change.

The author believes that university managers should find ways of retaining those they employed while at the same time creating a positive climate for young scholars with talent who could be encouraged to follow an academic career in African languages. A university's human resource division should consider the importance of recruiting and retaining academic and research staff for this discipline, and should try to address the problems through the establishment of a new kind of organization, capitalizing on talent, talent review, paying close attention to the age of academic staff members, quality assurance, and considering one of three generic strategies, namely cost leadership, focus or differentiation.

\section{References}

Beatty, P.T. \& Burroughs, L. 1999. Preparing for an aging workforce: The role of higher education. Education Gerontology 25:595-611.

Bossidy, L., Charan, R. \& Burck, C. 2002. Execution: The discipline of getting things done. London: Random House Business Books.

Burger, D., Cronjé, A. \& Tibane, E. 2003. South African Yearbook 2003/04. Pretoria: Government Communications (GCIS).

Cohn, J.M., Khurana, R. \& Reeves, L. 2005. Growing talent as if your business depended on it. Harvard Business Review, October, 62-70.

Codrington, G. 2007. Leap into new space: Jump before you are pushed. HR Future, Human Strategies for Business 3:32-33.

Gordon, G. 2002. The role of leadership and ownership in building an effective quality culture. Quality in Higher Education 8(1):97-106.

Gratton, L. 2002. Living strategy, putting people at the heart of corporate purpose. London: Prentice Hall.

Hamel, G. \& Getz, G. 2004. Funding growth in an age of austerity. Harvard Business Review. July/August, 76-84

Hewlett, S.A., Sherbin, L. \& Sumberg, K. 2009. How Gen Y \& Boomers will reshape your agenda. Harvard Business Review. July/August:71-76.

Joerres, J. \& Turcq, D. 2006. Rethinking the value of talent. Strategy and Business 43:1-8.

Koopman-Boyden, P.G. \& MacDonald, L. 2003. Ageing, work performance and managing ageing academics. Journal of Higher Education Policy and Management 25(1): May, 29-40.

Liston, C. 1999. Managing quality and standards. Buckingham: SRHE/Open UniversityPress.

Ministry of Education 1996. Green Paper on Higher Education Transformation. Pretoria: Department of Education.

Moleke, P. 2006. Finding work: Employment experiences of South African graduates. Cape Town: HSRC Press. 
Moody, H.R. 1998. Aging: Concepts and controversies ( $2^{\text {nd }}$ ed.). Thousand Oaks, CA: Pine Forge Press.

Moon, S.M. 2003. Personal talent. Higher Ability Studies 14(1), June:5-21.

Nkuna, P.H. 2006. Indigenous languages in higher education. New Agenda: South African Journal of Social and Economic Policy 23, $3^{\text {rd }}$ Quarter:30-36.

Ntuli, D. 2007. Graduates fail by degrees. Business Time Careers of the Sunday Times, April 1:1.

Porter, M.E. 1990. Competitive advantage of nations. New York: Free Press.

Spencer-Matthews, S. 2001. Enforced cultural change in academe: A practical case study: Implementing quality management systems in higher education. Assessment \& Evaluation in Higher Education 26(1):52-59.

Tam, M. 2002. University impact on student growth: A quality measure? Journal of Higher Education Policy and Management 24(2):211-218.

Thompson, D., Marshall, J. \& Waite, M. 2003. Revised \& updated illustrated Oxford dictionary. New York: Oxford University Press.

Ulrich, D. \& Smallwood, N. 2004. Capitalising on capabilities. Harvard Business Review. June, 119-127.

Weaver, J.W. 1999. Gerontology education: A new paradigm for the $21^{\text {st }}$ century. Educational Gerontology 25:479490.

Wilkinson, A. 2003. The impact of national transformation imperatives and quality monitoring on programme selfevaluation at a South African university: Lessons learned. Quality in Higher Education 9(2), July:161-167.

Wooldridge, A. 2006. The battle for brainpower. The Economist, $5^{\text {th }}$ October, http://www. Economist.com/ surveys. 
Copyright of South African Journal of African Languages is the property of University of Port Elizabeth, Department of African Languages and its content may not be copied or emailed to multiple sites or posted to a listserv without the copyright holder's express written permission. However, users may print, download, or email articles for individual use. 